\title{
Development of a Model Mobile Training Management to Improve Quality Outcome of Education and Training for Coastal Communities in East Java
}

\author{
*A A N A D P Yuda1, B Suratman'1, Y Riyanto ${ }^{1}$ \\ ${ }^{1}$ Department of Management Education, Universitas Negeri Surabaya, Indonesia
}

\begin{tabular}{l} 
Article Info \\
\hline Article history: \\
Received November 19, 2021 \\
Revised November 25, 2021 \\
Accepted November 26, 2021 \\
Available Online December 30, 2021
\end{tabular}

Keywords:

Management Model

Mobile Training

Model Practical

Quality Outcome

\begin{abstract}
This research aims to analyze the practicality of developing a mobile training management model to improve the quality of education and training outcomes for coastal communities in East Java at the Surabaya Shipping Polytechnic. This study uses a qualitative approach that is based on the philosophy of positivism. Research subjects are employees who are involved in the implementation of the training, management experts who are masters in their fields, and understand the training activities. This development research uses three kinds of data collection methods, namely observation, interviews, and documentation. The research procedure used development adapted from Borg and Gall. Based on the research analysis, it can be concluded that the development of a mobile training management model to improve the quality of the training results is practical. The practicality of the mobile training model is shown by a very good category of assessment responses by expert users of mobile training management model development product users and the audience. Then results of the product trial to the community received some input and suggestions on some of the findings of obstacles to the application of the model. This research implies that it can be used as a guideline by coastal communities to improve the quality of safety during shipping.
\end{abstract}

\section{INTRODUCTION}

This basic training for prospective seafarers is a central government program in producing seafarers who have basic safety awareness and expertise. Basic safety is the main requirement in sailing. This is motivated by the lack of awareness of safety in manning ships, especially on traditional ships. Results research that can be compiled from the National Transportation Safety Committee, it is stated that ship accidents that occurred in Indonesia caused more casualties due to the lack of provision of safety equipment that should be provided on each ship and the lack of knowledge and safety capabilities that should be mastered by seafarers, especially passenger ships (Hendrawan, 2017; Utomo, 2017).

Awareness of morning work safety for ship owners is important to understand and implement. In addition to ship owners, seafarers also need to have the ability and self-skill regarding the basics of ship safety (Rasheed, 2016). The Surabaya Shipping Polytechnic supports the central government's program in increasing safety awareness in sea transportation, thus the Surabaya Shipping Polytechnic makes a basic training program for prospective seafarers (Ahmadi, 2019). This program is implemented for coastal communities in East Java, both carried out based on collaboration between the local government and the Surabaya Shipping Polytechnic 
(Poltekpel Surabaya) or as a form of Corporate Social Responsibility (CSR) Poltekpel Surabaya (Febriana, 2018).

Initial observations were made on prospective sailors at the Surabaya Shipping Polytechnic Campus. Basic training for prospective seafarers is intended for people who will or have become seafarers on traditional ships or private vessels who have never received similar training. For some people who focus on discussing the shipping system, they can be sure to know how the basic safety SOP procedures are carried out (Suyono \& Nawawinetu, 2013). However, if the policies and training that have been carried out are not routine, there will be a loss of basic knowledge, so the potential for accidents on ships often occurs (Ardiansyah \& Boiziardi, 2021).

Efficient steps can be taken by implementing mobile training or mobile training (Anh et al., 2019; Chin et al., 2016; Bas \& Sarigoz, 2018) with the concept of a basic training team for prospective seafarers from the Surabaya Poltekpel visiting prospective seafarers in each area. With this method, it will be able to reduce training costs. The same budget will be issued if the training is carried out at the Surabaya Poltekpel. So that this method can produce more seafarers in terms of quantity. If this mobile training is carried out outside the Poltekpel Surabaya campus, then there must be prepared in terms of budget management (Prayogo, 2020), management of training facilities (Siregar, 2018), human resource management (HRM) involved (Nasution, 2017), and strategic management basic level seafarer training operations.

The development of training is not limited to holding basic training for prospective seafarers, but also regarding the final results of the training, both in terms of quality and absorption in the shipping job market (Sumardi, 2020). Education and training that involves the role of the government, moreover also involving the private sector will be able to facilitate the absorption of the resultant workforce so that the output can be seen (Rumondor, 2013). From some of these descriptions, this study aims to analyze the practicality of developing a mobile training management model to improve the quality of education and training outcomes for coastal communities in East Java at the Surabaya shipping polytechnic.

\section{RESEARCH METHOD}

\section{General Background}

This research uses a qualitative approach, namely a research method that is based on the philosophy of positivism. Judging from the research objectives, this type of research is development research that aims to develop mobile training management for coastal communities in East Java at the Surabaya Shipping Polytechnic which focuses on operational strategy management, budget management, human resource management, facilities management, and budget management.

\section{Research Subject}

Research subjects include employees who are involved in the implementation of the training. Like a management expert who masters his field and understands training activities. Then the research sample consisted of participants, the chief director, and polytechnic employees, as well as the local community around the participants.

\section{Data Collection}

This development research uses three kinds of data collection methods. 1) Participant observation conducted by the developer aims to obtain information about the ongoing basic training of prospective seafarers. 2) Interview respondents in-depth to obtain important information related to basic training for prospective seafarers, the information is adjusted to the research subject or respondent. 3) Documentation, Documentation is carried out by collecting primary and secondary data at the Surabaya Shipping Polytechnic. Primary data is obtained directly in the field when the training is carried out, the data can be in the form of photos of activities from the 
planning, preparation, implementation, and evaluation stages of the training. Recordings during interviews, as well as questionnaires distributed to research subjects.

\section{Research Procedure}

The development research design according to Brog and Gall's development research was then adapted in research on the development of a Mobile Training management model to improve the quality of education and training outcomes for coastal communities in East Java at the Surabaya Shipping Polytechnic. As for the stages that were adapted from stage 1 to stage 10, only stage 8 was not used, so this study has a flowchart of research procedures such as Figure 1.

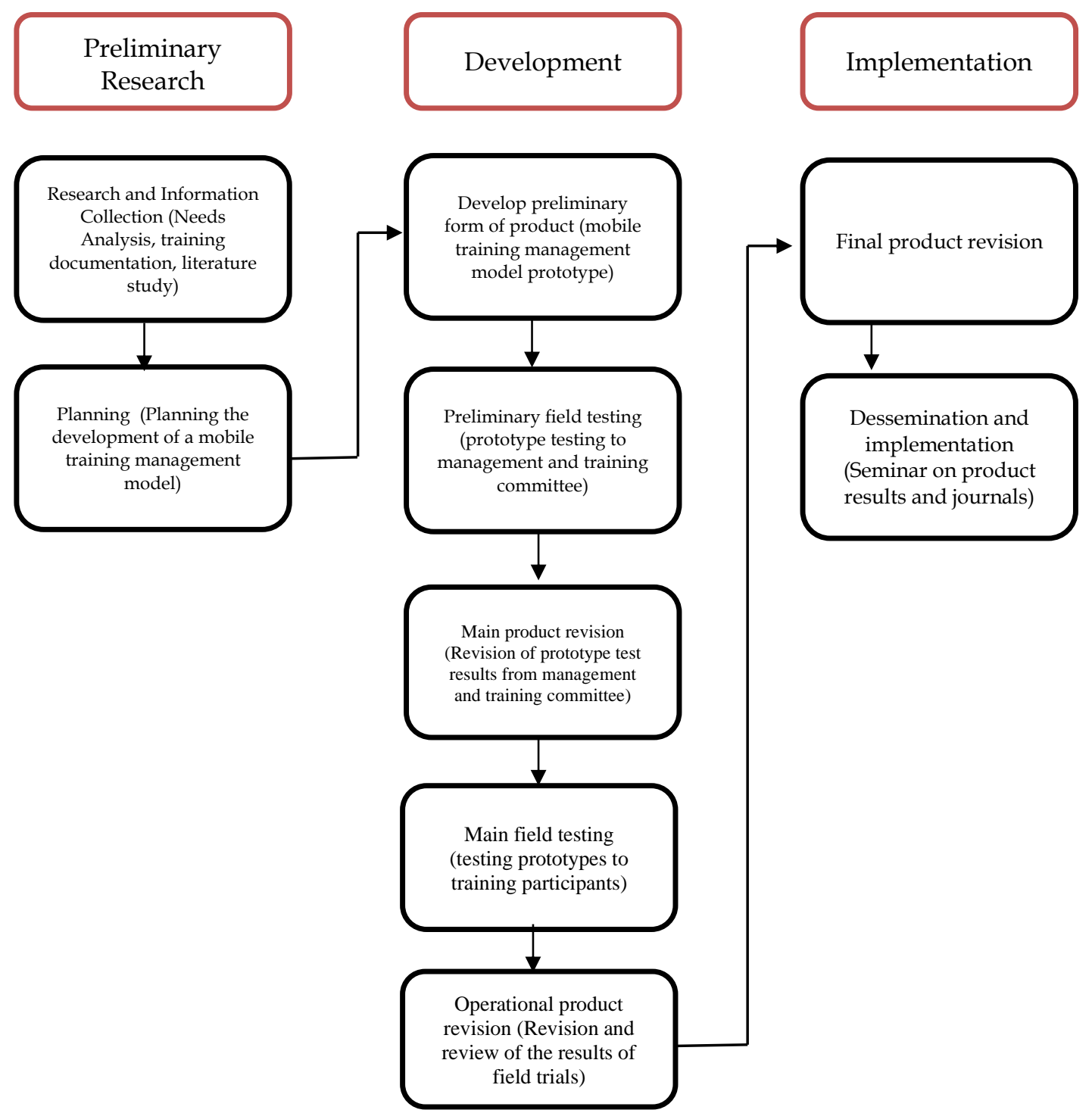

Figure 1. Flowchart procedure research

\section{Data Analysis}

The research data analysis to be carried out are; 1) Analysis of initial information, namely analyzing the identification of research problems, related to the implementation of basic training for prospective seafarers, as well as analysis related to existing mobile training models, analysis of cost management or training budgets carried out at Poltekpel Surabaya, and also analysis of resource management human resources and analysis of training facilities. 2) Design validation analysis, namely analyzing the manual that has been made, then also on the feasibility analysis. 3) Small-scale trial analysis, which is to reveal what variables play an important role or have a big influence on the mobile training process when carried out on a small scale. 4) Analysis of 
large-scale trials, namely analyzing in real terms everything that happens in the field to get results on a large scale. 5) Product development analysis, namely analyzing the end of product development, so that mobile training products are obtained that are in accordance with needs.

Based on the results of validation of the experts, it was found that all the instruments that had been developed were declared valid and reliable. Where the results of the validation of the experts obtained good categories both on educational management instruments and training management instruments. Then the results of trials I and II that have been assessed by experts and participants are presented in the categories, namely, $0<x 20$ is very poor; $21<x 40$ Less; 41 $<$ x 60 Enough, $61<$ x 80 Good; $81<$ x 100 Very good.

\section{RESULT AND DISCUSSION}

\section{A. Test Results Phase I and II}

After getting an assessment from expert validators and product development revisions, the next stage is a phase I trial. Phase I trials are carried out to find out the responses or responses from users of product development management models of mobile training. The developer provides product development in the form of a mobile training management model book to be studied by several people who were deliberately chosen by the developer to provide an assessment in the form of criticism and input on product development. Several people were selected with the consideration that they had a direct relationship with the implementation of skills training for seafarers. Direct experience in the implementation of education and training will provide a lot of input needed in perfecting product development.

The development product in form of a Mobile Training Management Model book has been improved as suggested by the assessors during the first stage of the trial. After the first stage of the trial, the next trial is referred to as the second stage of the trial. Phase II trial intends to maximize the results of product development in the form of a Mobile Training Management Model so that the development product is feasible to use after this research and development is completed. There are several stages carried out in the second phase of the trial, including.

\section{1) Product Presentation of Mobile Training Management Model Development to Surabaya Shipping Polytechnic Management}

Presentation of development products in the form of a Mobile Training Management Model book to the management of the Surabaya Shipping Polytechnic is the first step in the phase II trial.

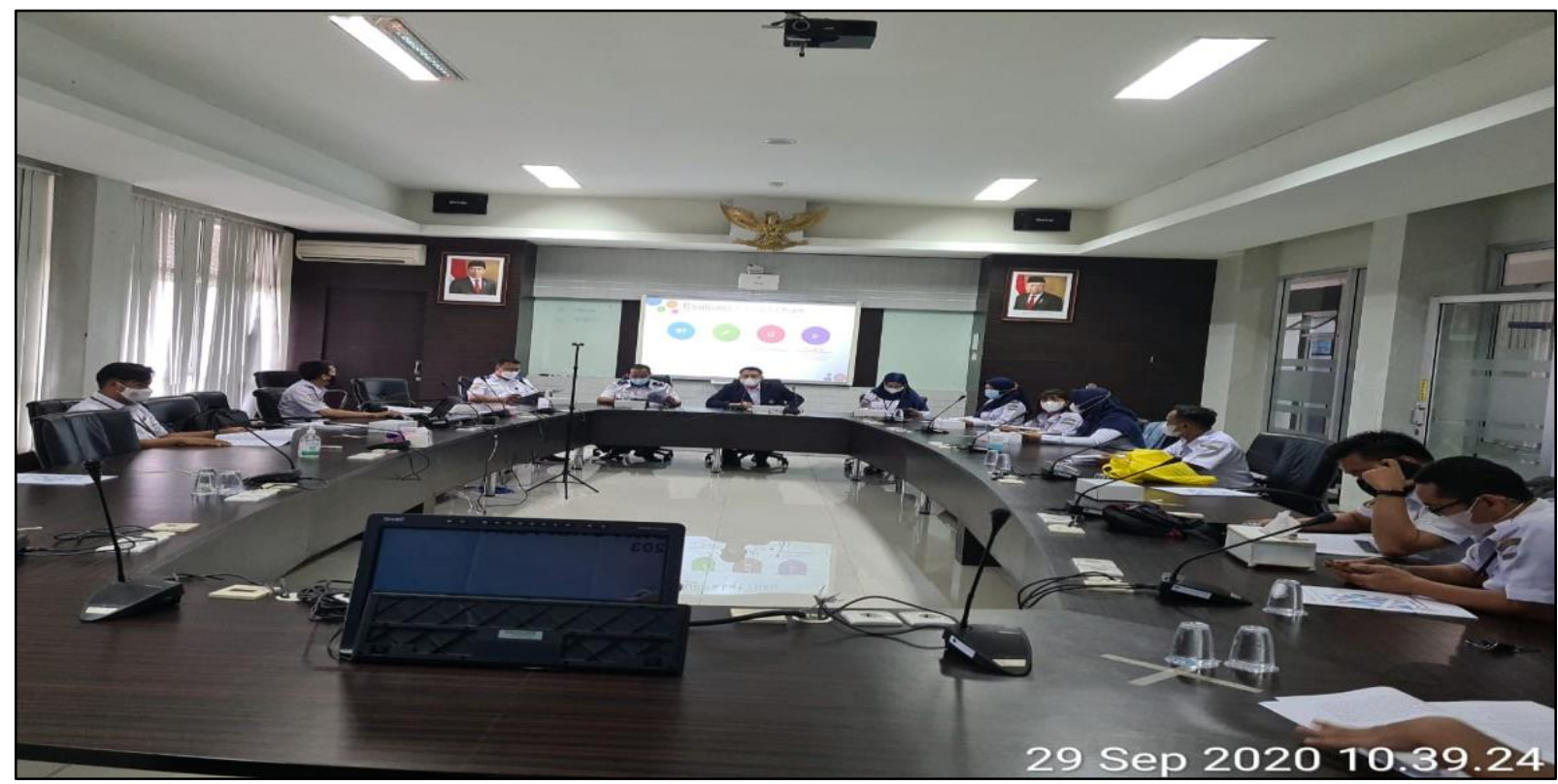

Figure 2. Presentation of the Mobile Training Management Model 
The result presentation was that the Mobile Training Management Model was well received and received a positive response from the audience. As a continuation of this presentation, adjustments were made regarding the implementation of basic skills training for fishermen in coastal areas. The concept is designed in the Mobile Training Management Model, namely the implementation of training carried out at the place of origin of the training participants. To obtain information that is coherent with the model offered, the developer will assist each unit related to the implementation of basic skills training for Seafarers. After the presentation process is done, the audience is invited to assess the model developed by the researcher. The instrument assessed has the same aspects as the instrument in the previous trial phase I. So that the results of the trial phase I and phase II are presented in Table 1 to Table 6.

\section{2) Assistance of the Mobile Training Management Model to SET and CRCS Section of Poltekpel Surabaya}

The SET Unit is the Skills Training and Education Unit, while the CRCS is the Center for Research and Community Service. After the presentation in front of the Surabaya Poltekpel management, the next step was to provide Mobile Training Management Model assistance to the Surabaya Poltekpel SET Unit and CRCS head along with the Surabaya Poltekpel staff. In this assistance, the discussion is more focused on the SOPs contained in the Mobile Training Management Model book which clearly shows the implementers and quality standards which are detailed with the completeness of the equipment, implementation time, and outputs that must be achieved. Using the details of the SOP will make it easier for the training team to use the Mobile Training Management Model to plan, carry out activities as well as control directly in the field. A followup and precise procedure will make it easier to implement without any clash of tasks between team members and reduce the question of what to do for the next process.

The assessment sheet that has been filled out by the assessors in the first phase of the trial, then the data processing is carried out using the average calculation of each aspect that has been assessed. Likewise, the second phase of the trial was assessed by the audience who attended the presentation of the mobile training management model. The following are the results of the average calculation for each aspect of the results of trial I and trial II.

Table 1. Score aspect display of the mobile training management model

\begin{tabular}{clcc}
\hline \multirow{2}{*}{ No } & \multicolumn{1}{c}{ Rating Points } & \multicolumn{2}{c}{ Average } \\
\cline { 3 - 4 } & \multicolumn{1}{c}{ The text displayed in the Mobile Training Management Model is easy to } \\
& read and understand & 3,9 & 3,9 \\
\hline 2 & Initial display font in Mobile Training Management Model is easy to read & 3,7 & 3,8 \\
\hline 3 & $\begin{array}{l}\text { The images provided by the Mobile Training Management Model make it } \\
\text { easier to understand the material }\end{array}$ & 3,6 & 3,7 \\
\hline 4 & $\begin{array}{l}\text { The image provided by the Mobile Training Management Model does not } \\
\text { cause perceptual bias }\end{array}$ & 3,6 & 3,8 \\
\hline 5 & $\begin{array}{l}\text { The size of the Mobile Training Management Model image is appropriate } \\
\text { and not too small }\end{array}$ & 3,4 & 3,3 \\
\hline 6 & The model display scheme is presented neatly and clearly read & 3,5 & 3,7 \\
\hline & Total & 21,7 & 22,1 \\
\hline
\end{tabular}

Table 1 shows the assessment of the display aspects of mobile training management in the first stage of the trial and the second stage of the trial. After being presented, it was obtained $91.9 \%$ which was categorized as very good. The highest score on the text items in the Mobile Training Model is easy to read and understand with a score of 3.9 while the lowest score on the image size items of the Mobile Training Model is appropriate and not too small with a score of 3.3. Where the minimum score is 1 the maximum score is 4 (Setiadi, 2016). In this case, it shows that the display aspect is very important. The innovative display will give a different impression 
to each audience who reads it (Noviar, 2016). Ningsih, \& Adesti, (2019) stated that a creative development model will attract readers and increase literacy interest. In addition to preparing interesting content, the background of display background also provides an initial attraction for readers.

Table 2. Scores of material aspects of the mobile training management model

\begin{tabular}{llcc}
\hline \multirow{2}{*}{ No } & \multicolumn{1}{c}{ Rating Points } & \multicolumn{2}{c}{ Average } \\
\cline { 3 - 4 } 1 & Material of model according to the context in the field & I & II \\
\hline 2 & $\begin{array}{l}\text { The material provided can stimulate thinking power and help } \\
\text { implement training activities }\end{array}$ & 3,1 & 3,5 \\
\hline 3 & $\begin{array}{l}\text { The material in the Mobile Training Management Model is related to } \\
\text { training activities in the field }\end{array}$ & 3,7 & 3,7 \\
\hline 4 & $\begin{array}{l}\text { The use of the Mobile Training Management Model can make it easier } \\
\text { to understand the tasks in training }\end{array}$ & 3,5 & 3,6 \\
\hline 5 & The SOP made provides clarity of tasks in the field & 3,8 & 3,9 \\
\hline 6 & The SOP made can represent the duties of each division & 3,6 & 3,7 \\
\hline 7 & Clarity of material in each chapter & 3,3 & 3,4 \\
\hline & Total & 24,7 & 25,5 \\
\hline
\end{tabular}

Table 2 shows the assessment aspects of mobile training management materials in the first stage of the trial and the second stage of the trial. The percentage value of the material aspect is $91.1 \%$ in the very good category. The highest score was obtained on the SOP items which were made to provide clarity of tasks in the field with a score of 3.9 indicating that the SOP made a major contribution in showing the clarity of tasks in the Mobile Training Management Model book. The lowest score on the item clarity of material in each chapter with a score of 3.5. Preparation of the material is very necessary for the successful performance of the trainees. (Mabruri et al., 2019) said that the material used during training must be by the context in the field to improve performance and training. In addition, clear SOPs are needed in each division. SOPs must be written in sentences and are clear, systematic, and easy to understand (Larasati, 2016).

Table 3. Scores of language aspects of the mobile training management model

\begin{tabular}{llcc}
\hline \multirow{2}{*}{ No } & \multicolumn{1}{c}{ Rating Points } & \multicolumn{2}{c}{ Average } \\
\cline { 2 - 4 } & \multicolumn{1}{c}{ II } \\
\hline 1 & $\begin{array}{l}\text { Sentences in the Mobile Training Management Model text are easy to } \\
\text { read and understand }\end{array}$ & 3,6 & 3,87 \\
\hline 2 & $\begin{array}{l}\text { The Mobile Training Management Model uses easy-to-understand } \\
\text { vocabulary }\end{array}$ & 3,5 & 3,67 \\
\hline 3 & $\begin{array}{l}\text { The Mobile Training Management Model uses easy-to-digest and } \\
\text { communicative language }\end{array}$ & 3,6 & 3,80 \\
\hline 4 & Language style does not cause perceptual bias & 3,4 & 3,60 \\
\hline 5 & Writing meets enhanced spelling & 3,5 & 3,73 \\
\hline & Total & 17,6 & 18,67 \\
\hline
\end{tabular}

Table 3 shows the assessment of linguistic aspects in the results of the first stage of the trial and the second stage of the trial. The percentage of this aspect is $93.5 \%$ which is categorized as very good. The linguistic aspect determines the understanding of the trainees in understanding the procedures or modules developed. Yusri et al (2015) stated that sentences presented in the easyto-digest and communicative language would make it easier for participants to understand instructions or concepts. In addition, the style of language used is minimal to avoid biased sentences, so as not to cause many perspectives. Turan \& Uzunboylu, (2019) showed that 
Development of a Model Mobile Training Management to Improve Quality Outcome of Education and Training for Coastal Communities in East Java

choosing the right language was able to improve the quality results of participants or respondents.

Table 4. Scores of systematic aspects of mobile training management model

\begin{tabular}{|c|c|c|c|}
\hline \multirow{2}{*}{ No } & \multirow{2}{*}{ Rating Points } & \multicolumn{2}{|c|}{ Average } \\
\hline & & I & II \\
\hline 1 & The material is presented in easy-to-understand stages & 3,6 & 3,8 \\
\hline 2 & The material is presented in a coherent manner & 3,3 & 3,7 \\
\hline 3 & Materials are classified according to the main task of each division & 3,7 & 3,7 \\
\hline \multirow[t]{2}{*}{4} & Between parts of the material has a relationship in each chapter & 3,5 & 3,6 \\
\hline & Total & 14,1 & 14,8 \\
\hline
\end{tabular}

Table 4 shows the results of the assessment of the systematic aspects of the mobile training management model in the first stage of the trial and the second stage of the trial. The results of the presentation showed a score of $93.3 \%$ which was categorized as very good. The highest score on the text items in the Mobile Training Model is easy to read and understand with a score of 3.9 while the lowest score on the items of language style does not cause a perception bias with a score of 3.5. A coherent presentation systematic makes the reader able to construct knowledge well. Michelson et al (2013) stated that in designing a module or management model book, each section between materials must have continuity and interrelationships to facilitate understanding.

Table 5. Scores of applicative aspects and up-to-date mobile training management model

\begin{tabular}{clcc}
\hline No & \multicolumn{1}{c}{ Rating Points } & \multicolumn{2}{c}{ Average } \\
\hline Applicative Aspect & I & II \\
\hline 1 & Easy to use Mobile Training Management Model instructions & 3,7 & 3,73 \\
\hline 2 & $\begin{array}{l}\text { Mobile Training Management Model in accordance with the context in } \\
\text { the field }\end{array}$ & 3,6 & 3,80 \\
\hline 3 & Users can imagine the tasks to be carried out & 3,4 & 3,53 \\
\hline 4 & Applicable level of Mobile Training Management Model if applied & 3,3 & 3,60 \\
\hline & Total & 14,0 & 14,67 \\
\hline Up-to-date Aspect & & \\
\hline 1 & $\begin{array}{l}\text { The contents of the Mobile Training Management Model material are } \\
\text { in accordance with the development of management science }\end{array}$ & 3,5 & 3,67 \\
\hline 2 & $\begin{array}{l}\text { The Mobile Training Management Model is contextual and can be } \\
\text { applied to current conditions }\end{array}$ & 3,5 & 3,53 \\
\hline 3 & Depth level of Mobile Training Model & 3,4 & 3,60 \\
\hline & Total & 10,4 & 10,80 \\
\hline
\end{tabular}

In addition to several aspects of the assessment that have been outlined in the previous table. Table 5 shows the results of the assessment of the applicable and up-to-date aspects. The percentage of applicative aspects is $93.3 \%$ which is categorized as very good. The thing that tends to be a point in assessing the applicative aspect is the extent to which the mobile training model can be applied by users. If the mobile training model is efficient, practical, and easy to use, the participants' performance results will also be faster and more efficient (Damopolii \& Kurniadi, 2019), then in the up-to-date aspect, the percentage is $91.6 \%$ which is categorized as very good too. The level of material in the mobile training is very good. This is in line with Ningsih \& Adesti, (2019) that a mobile training model that presents material depth will improve the quality of the results. 
Development of a Model Mobile Training Management to Improve Quality Outcome of Education and Training for Coastal Communities in East Java

https://doi.org/10.46627/silet.v2i3.86

Table 6. Scores of benefits aspects of the mobile training management model

\begin{tabular}{clccc}
\hline No & \multicolumn{1}{c}{ Rating Points } & \multicolumn{2}{c}{ Average } \\
\hline \multicolumn{5}{c}{ II } \\
\hline 1 & $\begin{array}{l}\text { Using the Mobile Training Management Model can make it easier to } \\
\text { understand the duties of each division }\end{array}$ & 3,8 & 3,9 \\
\hline 2 & $\begin{array}{l}\text { Using the Mobile Training Management Model can make it easier to } \\
\text { plan work }\end{array}$ & 3,7 & 3,8 \\
\hline 3 & $\begin{array}{l}\text { Using the Mobile Training Management } \\
\text { convenience in carrying out work }\end{array}$ & Model can provide & 3,5 & 3,5 \\
\hline 4 & $\begin{array}{l}\text { Using the Mobile Training Management Model can provide } \\
\text { convenience in job evaluation }\end{array}$ & 3,6 & 3,7 \\
\hline & Total & & 14,6 & 14,9 \\
\hline
\end{tabular}

Table 6 shows the results of the assessment of the benefits of the mobile training management model both in the first trial phase and the second trial phase. After being presented, $92.9 \%$ were categorized as very good. Audiences and experts consider that the development of this mobile training model is useful. Where the benefits obtained are to provide convenience in planning work, carrying out work, and evaluating work (Jurkowski, S., \& Hänze, M. 2015). The development of modules that have many benefits can be said to be practical and facilitate participants' understanding (Nurvitasari et al., 2021). Where the aspect of facilitating work activities is an important point in developing modules.

\section{B. Product Trial Results}

The product trial implementation in the form of a Mobile Training Management Model book was carried out with several agendas that followed the implementation of training activities organized by the Surabaya Shipping Polytechnic P3M. The implementation of this trial is adjusted to the standard operating procedures (SOP) in the Mobile Training Management Model. The stages of the agenda series and evaluation of the implementation of the Product Trial will be described in three parts, namely: 1) Finding obstacles in the field in the application of the Mobile Training Management Model, 2) Standard operating procedures (SOP) in the Mobile Training Management Model, 3) Values added from the application of the Mobile Training Management Model. Here is a description of each part.

\section{Finding obstacles in the field in the application of the Mobile Training Management Model}

Based on the analysis of constraints from several participant audiences in experiencing the developed mobile training, several obstacles were found. These obstacles are 1) data on the number of participants in the socialization of basic training programs that are out of sync; 2) In the administration and health selection (color blindness test) held at KUPP Branta Tlanakan Pamekasan, the administrative selection team that was supposed to work 2 days, ended up working up to 4 days; 3) The implementation of skills training on day 1 to day 6 is the delivery of theoretical material and is carried out using an online method, this is a problem regarding the absorption of training participants regarding the material to be delivered. The findings of some of these obstacles will serve as future evaluations in developing a much better and more practical mobile training. A good evaluation is an evaluation that involves developers and participants and also feels the use of the model (Rahayu \& Firmansyah, 2019).

\section{Standard operating procedure (SOP) in Mobile Training Management Model}

The implementation of the training flow is by the SOPs made. The implementation begins with socializing/informing the basic training program on shipping safety with a mobile training model to local agencies. Then the Surabaya Poltekpel sent a letter regarding the names that would be included in the basic shipping safety training with the status of prospective participants. After 
that, the Surabaya Poltekpel announced the results of the selection of the names of participants who were eligible to take part in basic shipping safety training. The training participants take part in the Medical check-up (MCU) for the publication of the seafarer's book before the final activity, as well as following the post-test and filling out questionnaires in the satisfaction survey for the implementation of the training.

Training that pays attention to SOPs can be safely maintained in conditions that have not been predicted. Training participants will also feel comfortable if the mobile training management model is prepared with SOPs (Musfah, 2015). Buvat et al., (2013) stated that everything designed with novelty still pays attention to the SOP in each agency. Because SOP is a minimum quality standard to prevent internal and external technical hazards (Carissa \& Nugroho, 2019). This is indicated by a positive response to the questionnaire given. Where the training participants feel the benefits of the results of the development of the mobile training model.

\section{The added value of implementing the Mobile Training Management Model}

The use of the Mobile Training Management Model provides added value in terms of human resource management (HR). HR is involved in the implementation team as users can easily understand the tasks that must be completed by each section and division because in the Mobile Training Management Model book there are tasks that must be completed along with the clarity of the quality standards of each task. The Mobile Training Management Model contributes in the form of added value in budget management in the form of budget savings. And the added value of the Mobile Training Management Model in operational management and the quality of training results (Painduri et al., 2020).

The training participants who attended the basic skills training were not only local fishermen but also some employees of the Branta Tlanakan Pamekasan Port Organizing Unit (KUPP) Office. Based on the experience of local fishermen when the BST practice instructor asked what safety equipment was available on the boat and what to do when an accident happened when the boat overturned or sank. There was one participant who answered that the ship did not have a life jacket as a buoy, so if there was an emergency he and the other crew members took empty jerry cans to save themselves so that they floated on the sea surface. When the instructor asked the training participants who work as fishermen, he confirmed that many ships were not equipped with standard safety equipment and were by the number of crew members. This situation should be a concern of the Branta Tlanakan Pamekasan Port Organizing Unit (KUPP) Office to follow up in the form of a ban on sailing ships before fulfilling safety equipment that is by standards and is by the crew, even if fishing vessels are owned by fishermen.

The added value of basic skills training with this mobile training model provides a lot of information and reveals facts, provides education, provides a direct experience so that the training provides a lot of learning experiences for training participants who incidentally are mostly fishermen (Yuliani et al., 2020). Of course, this learning experience cannot be found in the education and training courses held on campus.

\section{CONCLUSION}

It is concluded that the development of a mobile training management model to improve the quality of training results is practical. The practicality of the mobile training model is indicated by the very good rating response by expert users of the mobile training management model development product user and the audience. Then the results of the product trial to the community received some input and suggestions on some of the findings of obstacles to the application of the model. This research implies that it can be used as a guideline by coastal communities to improve the quality of safety during shipping. The limitation of this study is that it is limited to coastal communities in polytechnic East Java and sees its effect on the quality of the results. Further research is needed on the types of mobile training models with different conditions and with different competencies. 
Development of a Model Mobile Training Management to Improve Quality Outcome of Education and Training for Coastal Communities in East Java

https://doi.org/10.46627/silet.v2i3.86

\section{ACKNOWLEDGEMENTS}

Thank you to all ranks of the Surabaya Shipping Polytechnic for this research collaboration.

\section{REFERENCES}

Ahmadi, A. (2019). The application of CBA and SUG model for improving the quality of indonesian navy human resources. International Journal of Recent Technology and Engineering, 8(3), 393-399.

Anh, T. T., Luong, N. C., Niyato, D., Kim, D. I., \& Wang, L. C. (2019). Efficient training management for mobile crowd-machine learning: A deep reinforcement learning approach. IEEE Wireless Communications Letters, 8(5), 1345-1348

Ardiansyah, R., \& Boiziardi, A. S. (2021). Penerapan standar operasional prosedur PT. Pelni selaku operator kapal penumpang di pelabuhan teluk bayur. Normative Jurnal Ilmiah Hukum, 9(1 April), 39-53.

Bas, M., \& Sarigöz, O. (2018). Determining the readiness levels of pre-service teachers towards mobile learning in classroom management. Educational Research and Reviews, 13(10), 382-390.

Buvat, J., Maggi, M., Guay, A., \& Torres, L. O. (2013). Testosterone deficiency in men: systematic review and standard operating procedures for diagnosis and treatment. The journal of sexual medicine, 10(1), 245-284.

Carissa, R. D., \& Nugroho, F. (2019). Implementasi kebijakan pemenuhan layanan dasar dalam panti bagi penyandang terlantar melalui standar pelayanan minimal bidang sosial. Sosio Informa, 5(3).

Chin, A. G., Etudo, U., \& Harris, M. A. (2016). On mobile device security practices and training efficacy: An empirical study. Informatics in Education, 15(2).

Damopolii, I., \& Kurniadi, B. (2019).Training students metacognitive skill using mobile learning. In Journal of Physics: Conference Series, 1317(1), pp. 012185. IOP Publishing.

Febriana, M. (2018). Partisipasi masyarakat dalam program tanggung jawab sosial perusahaan pt. pelayaran baharimas kalimantan (Studi di desa sungai raya kecamatan sungai raya kabupaten kubu raya). Sociologiqu E-Jurnal Sosiologi, 5(3).

Hendrawan, A. (2017). Analisa keselamatan dan kesehatan kerja pada nelayan. Saintara: Jurnal Ilmiah Ilmu-Ilmu Maritim, 2(1), 12-23.

Jurkowski, S., \& Hänze, M. (2015). How to increase the benefits of cooperation: Effects of training in transactive communication on cooperative learning. British Journal of Educational Psychology, 85(3), 357-371.

Larasati, P. A. (2016). Pengembangan aparatur berbasis kompetensi dalam meningkatkan kualitas pelayanan perizinan di unit pelaksanaan teknis pelayanan perizinan terpadu (UPT P2T) Badan Penanaman Modal Provinsi Jawa Timur. Kebijakan Dan Manajemen Publik, 4(3), 243-255.

Mabruri, H., Ahmadi, F., \& Suminar, T. (2019). The development of science mobile learning media to improve primary students learning achievements. Journal of Primary Education, 8(1), 108116

Michelson, L., Sugai, D. P., Wood, R. P., \& Kazdin, A. E. (2013). Social skills assessment and training with children: An empirically based handbook. Springer Science \& Business Media.

Musfah, J. (2015). Manajemen pendidikan teori, kebijakan, dan praktik. Kencana.

Nasution, W. P. (2017). Implementasi diklat kepemimpinan tingkat IV pada Badan Diklat Provinsi Bengkulu (Studi deskriptif kualitatif tentang dukungan sumber daya aparatur, anggaran, dan fasilitas diklat). Jurnal Governance dan Administrasi Publik, 1(2), 39-45. 
Ningsih, S., \& Adesti, A. (2019). Pengembangan mobile learning berbasis android pada mata kuliah strategi pembelajaran Universitas Baturaja. Edcomtech Jurnal Kajian Teknologi Pendidikan, 4(2), 163-172.

Nurvitasari, S., Madlazim, \& Wasis. (2021). Development of OrSAEv model learning: Preliminary study of students' prepareness facing volcanic eruption disaster. Studies in Learning and Teaching, 2(1), 41-51. https:// doi.org/10.46627/ silet.v2i1.58

Noviar, D. (2016). Pengembangan ensiklopedi Biologi mobile berbasis android dalam rangka implementasi Kurikulum 2013. Jurnal Cakrawala Pendidikan, 35(2).

Parinduri, L., Hasdiana, S., Purba, P. B., Sudarso, A., Marzuki, I., Armus, R., ... \& Refelino, J. (2020). Manajemen operasional: teori dan strategi. Yayasan Kita Menulis.

Prayogo, D. (2020). Pelatihan Basic Safety Training (BST) kepada nelayan tegal untuk menunjang keselamatan pelayaran. E-Dimas: Jurnal Pengabdian kepada Masyarakat, 11(2), 236-239.

Rahayu, G. D. S., \& Firmansyah, D. (2019). Pengembangan pembelajaran inovatif berbasis pendampingan bagi guru sekolah dasar. Abdimas Siliwangi, 1(1), 17-25.

Rasheed, E. K. (2016). A program applying professional safety basics in construction projects. Journal of Engineering, 22(4), 1-21.

Rumondor, V. W. (2013). Motivasi, disiplin kerja, dan kepemimpinan terhadap produktivitas kerja pada badan kepegawaian dan diklat daerah Minahasa Selatan. Jurnal EMBA: Jurnal Riset Ekonomi, Manajemen, Bisnis dan Akuntansi, 1(4).

Setiadi, H. (2016). Pelaksanaan penilaian pada Kurikulum 2013. Jurnal Penelitian dan Evaluasi Pendidikan, 20(2), 166-178.

Siregar, E. (2018). Faktor-faktor yang mempengaruhi manajemen pendidikan dan pelatihan (Diklat) dalam upaya pengembangan sumber daya manusia (SDM). Jurnal Dinamika Pendidikan, 11(2), 153-166.

Sumardi, S. (2020). Analisis kualitas pelayanan transportasi laut (survei pada perusahaan pelayaran di Pelabuhan Tanjung Priok, 2015). Majalah Ilmiah Bahari Jogja, 18(1), 37-56.

Suyono, K. Z., \& Nawawinetu, E. D. (2013). Hubungan antara faktor pembentuk budaya keselamatan kerja dengan safety behavior di PT. Dokdan Perkapalan Surabaya Unit Hull Construction. The Indonesian Journal of Occupational Safety and Health, 2(1), 67-74.

Turan Çimşir, B., \& Uzunboylu, H. (2019). Awareness training for sustainable development: Development, implementation and evaluation of a mobile application. Sustainability, 11(3), 611.

Utomo, H. (2017). Siapa yang bertanggung jawab menurut hukum dalam kecelakaan kapal (legally responsible parties in ship accident). Dari Redaksi, 57.

Yuliani, M., Simarmata, J., Susanti, S. S., Mahawati, E., Sudra, R. I., Dwiyanto, H., ... \& Yuniwati, I. (2020). Pembelajaran daring untuk pendidikan: teori dan penerapan. Yayasan Kita Menulis.

Yusri, I. K., Goodwin, R., \& Mooney, C. (2015). Teachers and mobile learning perception: towards a conceptual model of mobile learning for training. Procedia-Social and Behavioral Sciences, 176, 425-430. 
Development of a Model Mobile Training Management to Improve Quality Outcome of Education and Training for Coastal Communities in East Java

Author (s):

* Anak Agung Ngurah Ade Dwi Putra Yuda (Corresponding Author) Department of Management Education

Universitas Negeri Surabaya

Jl. Raya Kampus Unesa, Lidah Wetan, Kec. Lakarsantri, Surabaya, Indonesia

Email: anak.17070976203@mhs.unesa.ac.id

Bambang Suratman

Department of Management Education

Universitas Negeri Surabaya

Jl. Raya Kampus Unesa, Lidah Wetan, Kec. Lakarsantri, Surabaya, Indonesia

Email: bambangsuratman@unesa.ac.id

Yatim Riyanto

Department of Management Education

Universitas Negeri Surabaya

Jl. Raya Kampus Unesa, Lidah Wetan, Kec. Lakarsantri, Surabaya, Indonesia

Email: yatimriyanto@unesa.ac.id 